\title{
Construction of a Three-Dimensional Human Skin Model Consisting of Keratinocytes, Dendritic Cells and Fibroblasts and Application of This Model for Alternative Animal Testing of Immune-Sensitizing Compounds*
}

\author{
Tadashi Uchino, Yoshiaki Ikarashi, Hiroshi Tokunaga \\ National Institute of Health Sciences**
}

\begin{abstract}
In order to establish in vitro evaluation of the sensitization of human skin, we attempted to make a three-dimensional human skin model consisting of three different cells, dendritic cells, keratinocytes and fibroblasts. The viability of the cells in the human skin model was observed after staining with hematoxylin and eosin. After 1114-day incubation (horny layer was initially observed), the three-dimensional human skin model was used for experiments. Due to 2,4-dinitrochlorobenzene (DNCB) under a non-cytotoxic dose, the keratinocytes and dendritic cells in the human skin model significantly induced IL-4 release into the incubating medium and dendritic cells induced CD86 expression. On the other hand, with sodium dodecyl sulfate (SDS ; non-sensitizer), the keratinocytes and dendritic cells did not significantly induce IL-4 release and the dendritic cells did not induce CD86 expression. The results suggested that this three-dimensional human skin model with dendritic cells could be applied as an alternative to animal testing of immune-sensitizing compounds.
\end{abstract}

Key words : three-dimensional human skin model, CD86, dendritic cells, keratinocytes, fibroblasts, immunesensitizing compounds, DNCB, IL-4, in vitro evaluation, cytotoxicity

\section{Introduction}

For the safety of cosmetic ingredients, immune-sensitizing is important. Unfortunately, these are no in vitro human skin models applicable to the evaluation of immune-sensitizing compounds. Recently, to study an in vitro evaluation method of immune-sensitizing compounds, normal human dendrite cells were used. De Smedt et al. ${ }^{1)}$ reported that after 24-h exposure of normal human dendrite cells to $\mathrm{NiCl}_{2}$, the $\mathrm{CD} 86+$ expression on cells and IL-6 production should significantly increase, but there were no reactions in the case of sodium dodecyl sulfate (SDS). Furue et al. ${ }^{2)}$ reported that keratinocytes produce various kinds of cytokines (IL-1, TNF- $\alpha$, GM-CSF, etc.) and initiated survival and functional maturation of dendritic cells. Yoshida et al. ${ }^{3)}$ reported that after 24-h exposure of the human monocytic leukemia cell line (THP-1) for h-CLAT (human Cell Line Activation Test) method to 2,4-dinitrochlorobenzene (DNCB), CD86 expression and IL-1 $\beta$ production should significantly increase, but there were no reactions in the case of SDS. However, these models were single cell culture models with few keratinocytes so they induced immunoreactions with much less immune-sensitizing compound than real human skin. In addition, it was

\footnotetext{
* Received September 25, 2006

** 1-18-1, Kamiyoga, Setagaya-ku, Tokyo 158-8501, Japan
} 
difficult to apply water-insoluble samples (ex. creams or milky lotions) to these models.

Many skin models have already been established for the evaluation of water insoluble sample effects on the human skin. Bell et al. ${ }^{4}$ have reported a full thickness human skin model consisting of the dermis and epidermis, which mimicked real human skin. Rheins et al. ${ }^{5)}$ reported a new three dimensional human skin model (Skin ${ }^{2}{ }^{\mathrm{TM}}$ ZK1300, constructed of fibroblasts and keratinocytes) from which, after irradiation with ultraviolet B (UVB), prostaglandin $\mathrm{E}_{2}\left(\mathrm{PGE}_{2}\right)$ and interleukin (IL) $-1 \alpha$ were released. Morota et al. ${ }^{6,7)}$ reported a new three dimensional human skin model (constructed of fibroblasts and keratinocytes) and evaluated skin irritancy against 10 compounds. The result suggested that MTT and neutral red (NR) assays should show good correlation with in vivo scores, but these models did not have immunoreactible cells (like dendritic cells) so they could not be used for the evaluation of skin sensitization.

The aim of this study was to construct a three-dimensional human skin model consisting of dendritic cells, keratinocytes and fibroblasts and to apply this model the in vitro evaluation of immune-sensitizing compounds.

\section{Materials and Methods}

\subsection{Cells and medium}

Normal human skin fibroblasts (NHSF) 46 and human epidermoid carcinoma (A431) were purchased from Riken Cell Bank (Tsukuba, Japan). Normal human dendritic cells (NHDC; CD86+) were purchased from Cambrex Co. (USA).

\subsection{Reagents}

Type-I collagen was purchased from Nitta-gelatin Co. (Tokyo, Japan). Other materials were purchased from Wako Chemicals (Osaka, Japan).

\subsection{Procedure of constructing three-dimensional human skin model (see Fig.-1)}

Ten milliliters of $3 \times$ DMEM, $2.2 \mathrm{~mL}$ of FBS, $2.8 \mathrm{~mL}$ of DMEM- $10 \%$ fetal bovine serum (FBS), $10 \mathrm{~mL}$ of Type-I collagen (Cell matrix Type-I A $3.0 \mathrm{mg} / \mathrm{mL}, \mathrm{pH} 3)$ and $5 \mathrm{~mL}$ of NHSF46 $\left(2.4 \times 10^{5}\right.$ cells $/ \mathrm{mL}$ ) in DMEM-10\% FBS were added to an ice-cooled 50-mL plastic tube and mixed, and then each $5 \mathrm{~mL}$ of the mixture was placed in a $60 \mathrm{~mm}$ culture dish with DMEM-10\% FBS and cultured at $37^{\circ} \mathrm{C}, 5 \% \mathrm{CO}_{2}$, humidity above $90 \%$ for 7 days. The culture medium was changed to a mixture of DMEM-10\% FBS and EpiLife KG (keratinocyte growth medium)-2 (Kurabo Co., Osaka, Japan) $(1: 1)$ and underwent 3 -h incubation at $37^{\circ} \mathrm{C}, 5 \% \mathrm{CO}_{2}$, and humidity above $90 \%$. After incubation, the culture medium was changed to EpiLife KG-2 and underwent 3-h incubation at $37^{\circ} \mathrm{C}, 5 \% \mathrm{CO}_{2}$, and humidity above $90 \%$. Next, NHSF46 in collagen gel was placed on a plastic ring (outer size 2.2 $\mathrm{cm}$, inner size $1.0 \mathrm{~cm}$ ) and then placed in a six-well plate. A glass ring (Cloning ring, outer size $1.2 \mathrm{~cm}$, inner size $1.0 \mathrm{~cm}$, Asahi Technoglass Co., Tokyo Japan) was then placed on the collagen gel. One milliliter of Type-I collagen and $2 \mathrm{~mL}$ of NHDC $\left(3 \times 10^{5}\right.$ cells $\left./ \mathrm{mL}\right)$ in LGM (lymphocyte growth medium) $-3-5 \%$ human plasma were added to an ice-cooled $15-\mathrm{mL}$ plastic tube and mixed, and then each $0.5 \mathrm{~mL}$ of the mixture was placed in a glass ring for 2-h incubation at $37^{\circ} \mathrm{C}, 5 \% \mathrm{CO}_{2}$, and humidity above $90 \%$. After incubation, $\mathrm{A} 431\left(1 \times 10^{6}\right.$ cells $\left./ \mathrm{mL}\right)$ in $0.2 \mathrm{~mL}$ of EpiLife KG-2 was added to the glass ring and incubated for $1 \mathrm{~h}$. Two $\mathrm{mL}$ of EpiLife KG-2 was then added to each well. After $24-\mathrm{h}$ incubation at $37^{\circ} \mathrm{C}, 5 \% \mathrm{CO}_{2}$, and humidity above $90 \%, 2 \mathrm{~mL}$ of the mixture of DMEM-10\% FBS, EpiLife KG-2 and LGM-3-5\% human plasma (1:1:1) including $1.8 \mathrm{mmol} / \mathrm{L}$ of $\mathrm{Ca}^{2+}$ and $50 \mu \mathrm{g} / \mathrm{mL}$ of ascorbic acid (three-dimensional culture medium) were added. After 24-h incubation, the medium was removed. One $\mathrm{mL}$ of fresh three-dimensional culture medium was added to the surface of the three-dimensional human skin model consisting of keratinocytes, dendritic cells and fibroblasts (KDF-Skin) exposed to air (Fig. -1 ). The three- 
dimensional human skin model was incubated for 14 days to complete the structure of the skin model. In order to perform histochemical studies on the skin model, it was fixed in $10 \%$ formalin neutral buffer solution (for $24 \mathrm{~h}$ ), embedded in paraffin, and stained with hematoxylin and eosin (HE). The surface marker expression (CD86) of NHDC was analyzed by immunostaining.

\subsection{Procedure of incubating NHDC in collagen gel}

One $\mathrm{mL}$ of Type-I collagen and $2 \mathrm{~mL}$ of NHDC $\left(3 \times 10^{5}\right.$ cells $\left./ \mathrm{mL}\right)$ in LGM-3-5\% human plasma were added to an ice-cooled 15-mL plastic tube and mixed, and then each $0.5 \mathrm{~mL}$ of the mixture was placed in a 24-well plate for 24-h incubation at $37^{\circ} \mathrm{C}, 5 \% \mathrm{CO}_{2}$, and humidity above $90 \%$. After incubation, $0.5 \mathrm{~mL}$ of LGM-3-5\% human plasma were added to wells, and incubated for 3 days at $37^{\circ} \mathrm{C}, 5 \% \mathrm{CO}_{2}$, and humidity above $90 \%$. NHDC was fixed in $10 \%$ formalin neutral buffer solution, embedded in paraffin, and stained with HE. CD86 expression of NHDC was analyzed by immunostaining.

\subsection{Antibodies}

The primary antibody was used at $10 \mu \mathrm{g} / \mathrm{mL}$ for mouse monoclonal anti-human CD86 (Daco Cytomation Inc.) and the secondary antibodies were used at $0.5 \%$ for polyclonal goat anti-mouse (Daco Cytomation Inc.).

\subsection{Immunostaining}

$\mathrm{HE}$ and immunostaining were performed according to Applied Medical Research Co. The paraffin block of KDFSkin was dried, and the paraffin removed and washed. Then $80 \%$ methanol and $0.6 \%$ hydrogen peroxide were added, and after 30-min incubation, the slides were washed with water and $3 \%$ hydrogen peroxide was added, and then after 15-min incubation, the slides were washed with water and treated with TBST $(50 \mathrm{mmol} / \mathrm{L}$ Tris- $\mathrm{HCl}$, $\mathrm{pH} 7.6$

DMEM-10\% FBS+ Cellmatrix-Type I A+ NHSF46 $2 \times 10^{5}$ cells/well
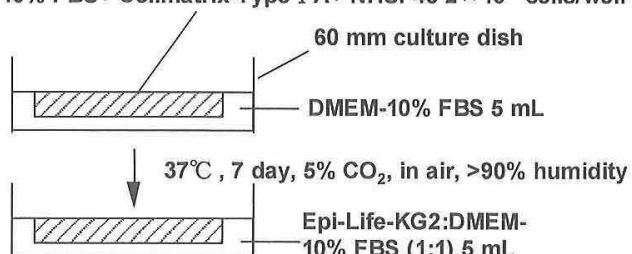

$10 \%$ FBS (1:1) $5 \mathrm{~mL}$

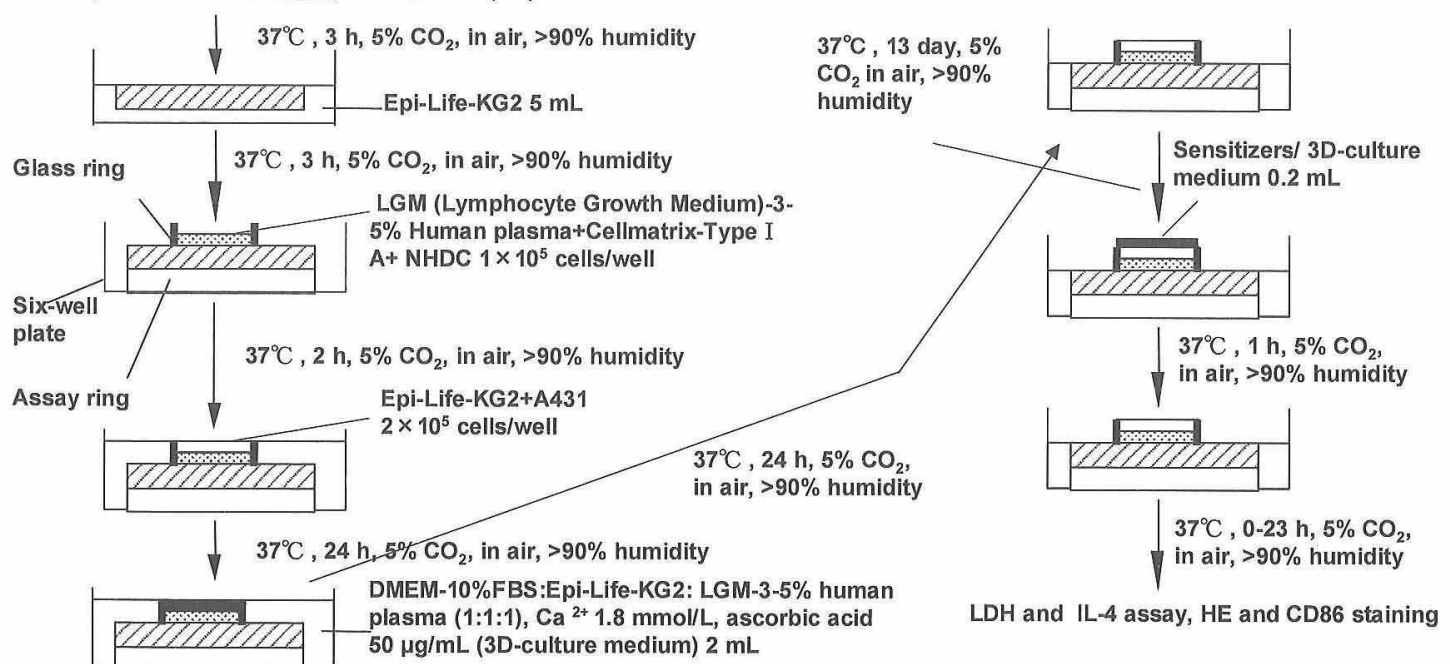

Fig. -1 Procedure for establishing KDF-Skin. 
including $0.15 \mathrm{mmol} / \mathrm{L} \mathrm{NaCl}$ and $0.05 \%$ Tween) for $5 \mathrm{~min}$. After blocking non-specific binding with $10 \%$ normal goat serum, the primary antibody was added and incubated at $4{ }^{\circ} \mathrm{C}$ overnight. Secondary antibodies were then added after washing with TBST and incubated at room temperature (r.t.) for $30 \mathrm{~min}$ following streptavidine reaction (r.t. for $30 \mathrm{~min}$ ). Detection was done using 3,3'-diaminobenzidine tetrachloride (DAB) (Waco Chemicals). Slides were stained with Mayer's hematoxylin (Daco Cytomation Inc.) to identify cell morphology and negative cells in blue.

\subsection{Treatment of chemicals}

One $\mathrm{mL}$ of fresh three-dimensional culture medium was added to KDF-Skin and after 13 days' incubation, DNCB $(0-2 \mathrm{mmol} / \mathrm{L}$ ) in $0.2 \mathrm{~mL}$ of three-dimensional culture medium was put onto the surface of KDF-Skin (see Fig. -1 ) for $1 \mathrm{~h}$. LGM-3-5\% human plasma $0.5 \mathrm{~mL}$ was added onto NHDC in collagen gel and after 4 days' incubation, NHDC was exposed to DNCB $(0-1 \mathrm{mmol} / \mathrm{L})$ in $0.2 \mathrm{~mL}$ of LGM-3-5\% human plasma. Culture medium was collected into microtubes after 1-h, 4-h and 24-h incubation. After 24-h incubation, $10 \%$ formalin neutral buffer solution was added to the skin model or NHDC in collagen gel, which was then stained with HE. The expression of CD86 on the dendritic cells of the skin model was analyzed by immunostaining.

\subsection{LDH assay}

A mixture of collected culture medium $(10 \mu \mathrm{L})$ and PBS $(40 \mu \mathrm{L})$ was placed into a 96-well microplate, $50 \mu \mathrm{L}$ of reagent (nitro blue tetrazolium $(0.74 \mathrm{mg} / \mathrm{mL})$, diaphorase and NAD $(50 \mathrm{mg} / \mathrm{mL})$ dissolved in lithium DL-lactate buffer $(50 \mathrm{mg} / \mathrm{mL}, \mathrm{pH} 9.0)$ ) was added to the wells and then the microplates were incubated at room temperature for $45 \mathrm{~min}$. On the addition of $100 \mu \mathrm{L}$ of $0.5 \mathrm{~mol} / \mathrm{L} \mathrm{HCl}$ as a stopping reagent, absorbance was measured at $570 \mathrm{~nm}$.

\subsection{IL-4 assay}

Each well was rinsed immediately with Wash Buffer $(0.5 \mathrm{~mL} / \mathrm{L}$ of Tween 20 in PBS $)$ and then $50 \mu \mathrm{L}$ of cell supernatant, $50 \mu \mathrm{L}$ of medium and $100 \mu \mathrm{L}$ of acetylcholinesterase ; IL-4 Fab' Conjugate solution was added to each well. After incubation at $4^{\circ} \mathrm{C}$ for $18 \mathrm{~h}$, the wells were rinsed five times with the Wash Buffer, and $200 \mu \mathrm{L}$ of Ellman' $\mathrm{s}$ Reagent was added to the wells. Absorbance at $405 \mathrm{~nm}$ was then measured using a microplate reader and the concentration of IL-4 was calculated based on the absorbance of standards.

\subsection{Statistical analysis}

Significant differences from the control were evaluated by Student's $t$-test.

\section{Results}

\subsection{Histochemical studies}

First, we investigated the exchange of a histochemical cross-section of KDF-Skin following the incubation time (Figs.-2 and 3). After a 3-day incubation, there were two layers of epidermis (Fig.-3(a)). After a 7-day incubation, epidermis layers had increased additionally, but the horny layer was not developed (Fig. -3(b)). After an 11-day incubation, the epidermis layers were increasing, and the horny layer was observed because in the surface layer, keratinocyte nuclei disappeared and the cells became flatter in comparison with the base layer (Fig.-3 (c)). After a 14-day incubation, epidermis layers were not increasing (Figs. -2 and $3(\mathrm{e})$ ). The fibroblast layer did not change during 14 days' incubation (Fig.-3(d)).

\subsection{Immunofunction of KDF-Skin}

In order to check the immunofunction of NHDC cells in KDF-Skin, we investigated the change in the expression of CD86 on dendritic cells (cell membrane antigen of NHDC) following the incubation time by immunostaining. When incubating for 7 days, the expression of CD86 + was the strongest, but after the 14-day incubation, the ex- 


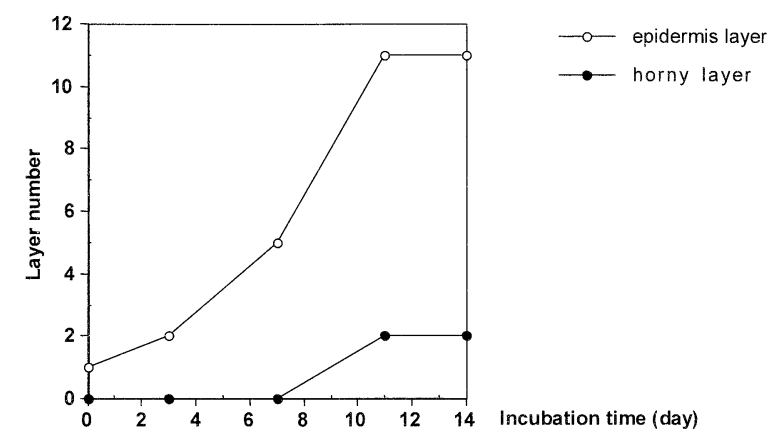

Fig. -2 Effect of incubation time on the number of epidermal and horny layers in KDF-Skin.

pression of CD86 + was moderate and still observed (Fig. -4 ).

\subsection{Effect of immune-sensitizing compounds on the immunofunction of KDF-Skin}

From 0-2 mmol/L of DNCB there was no release of LDH from KDF-Skin. Exposure to $0.5 \mathrm{mmol} / \mathrm{L} \mathrm{DNCB} \mathrm{did}$ not significantly release IL-4, and CD86 expression did not induce the dendritic cells of the skin model ; however, 1 mmol/L DNCB induced moderate IL-4 release and CD86 expression. Two mmol/L of DNCB significantly released IL-4, and CD86 expression was strong (Table 1). On the other hand, $1 \mathrm{mmol} / \mathrm{L}$ SDS did not significantly release IL-4, and CD86 expression did not induce the dendritic cells (Table 1). One mmol/L of SDS did not significantly release LDH from KDF-Skin ; however, $5 \mathrm{mmol} / \mathrm{L}$ SDS significantly released LDH.

\subsection{Effect of immune-sensitizing compounds on the immunofunction of NHDC in collagen gel}

From $0^{-1} \mathrm{mmol} / \mathrm{L}$ of DNCB did not release any LDH from NHDC in collagen gel. Exposure to $0.2 \mathrm{mmol} / \mathrm{L}$ DNCB induced CD86 expression appearing on dendritic cells. One mmol/L of DNCB induced CD86 expression appearing òn dendritic cells (Table 2). IL-4 release could not be detected.

\section{Discussion}

After an 11-day incubation, a horny layer was observed and after a 14-day incubation, three kinds of cells, keratinocytes, dendritic cells and fibroblasts, were alive, and the expression of CD86 in NHDC persisted. The results suggested that within 11-14 day' incubation, KDF-Skin should be used for the applied to study of effect of test chemicals on CD86 expression.

It was not clear whether the detailed mechanism of CD86 expression on dendritic cells was due to DNCB, but Aiba et al. ${ }^{87}$ reported that $30 \mu \mathrm{mol} / \mathrm{L}$ DNCB induced the CD86 expression of the monolayer of human monocytederived dendritic cells and anti-TNF- $\alpha$ or anti-IL-1 $\beta$ antibodies suppressed the expression significantly, so they demonstrated that DNCB seemed to first stimulate dendritic cells to secrete IL- $\beta$ or TNF- $\alpha$ which then induced their CD86 expression. Staquet et al. ${ }^{9)}$ reported that $38 \mu \mathrm{mol} / \mathrm{L}$ DNCB induced the CD86 expression of the monolayer of dendritic cells generated from human monocytes. Yoshida et al. ${ }^{3)}$ reported that $3 \mu \mathrm{g} / \mathrm{mL} \mathrm{DNCB}$ released IL- $1 \beta$ and induced CD86 expression in THP- 1 cells. Coquette et al. ${ }^{10)}$ reported that $1 \mathrm{mg} / \mathrm{mL} \mathrm{DNCB}$ released IL- $\alpha$ and IL-8 from reconstructed human epidermis. Ryu et al. ${ }^{11)}$ reported that IL-4 and granulocyte-macrophage colonystimulating factor increased the expression of CD86. Immune-sensitizing compounds such as DNCB, methylparaben, and benzethonium chloride also released IL- $1 \beta$ and IL- 4 from the A431 monolayer. ${ }^{12)}$ These results suggested that DNCB should release cytokines (IL-1, IL-4, TNF- $\alpha$, etc.) from A431 and induce CD86 expression in NHDC. Further study should investigate the effect of DNCB on cytokines and the effect of anti-cytokine antibody on CD86 


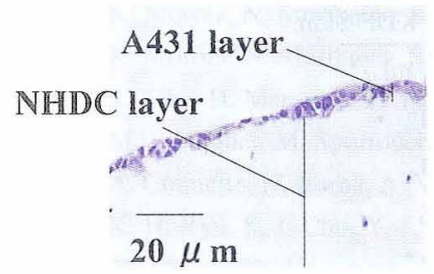

(a) 3 days, A431 and NHDC layer

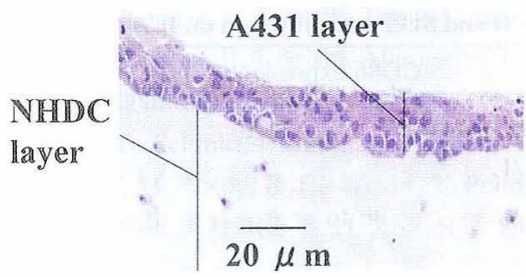

(b) 7 days, A431 and NHDC layer

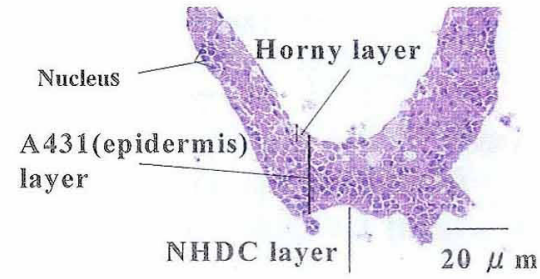

(c) 11 days, A431 and NHDC layer

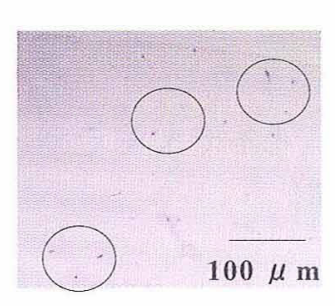

(d) 11 days, NHSF46 layer

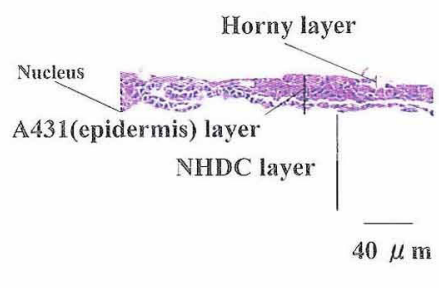

(e) 14 days, A431 and NHDC layer

Fig. -3 Histological cross-section of KDF-Skin after staining with hematoxylin and eosin. Skin model was incubated for 3 days (a), 7 days (b), 11 days ( (c) and (d)) or 14 days (e).

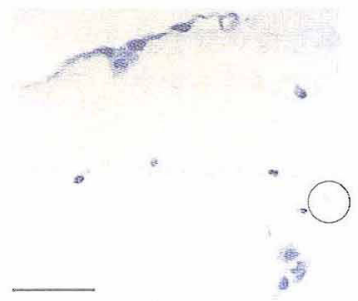

$40 \mu \mathrm{m}$

3 days, CD86 Expression : \pm

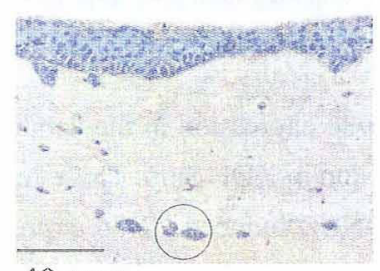

$40 \mu \mathrm{m}$

7 days, CD86 Expression : ++

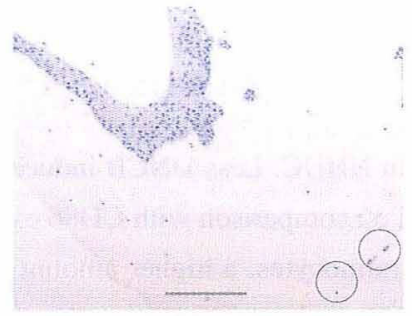

$80 \mu \mathrm{m}$

11 days, CD86 Expression : +

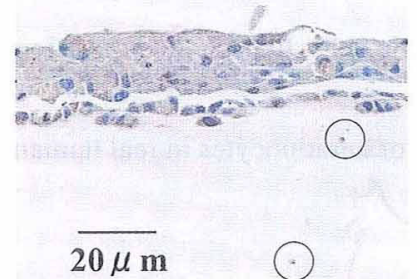

14 days : CD86 Expression : +

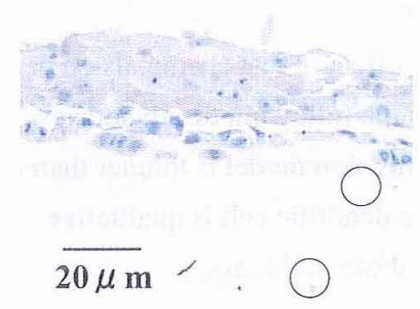

14 days : CD86 Expression :- -

Fig. -4 Histological cross-section of KDF-Skin immunostaining with CD86.

Skin model was incubated for 3-14 days. CD86 immunostaining :-, blue ; \pm , gray ;

+ , light brown ; + to ++ , brown ; ++ , dark brown. 
Table-1 Effect of DNCB and SDS concentration on IL-4 release from KDF-Skin.

\begin{tabular}{lcc}
\hline \multicolumn{1}{c}{ Compound } & CD86 expression & IL-4 release $(\mathrm{pg} / \mathrm{mL})^{\mathrm{a}}$ \\
\hline Control & + & $26.8 \pm 10.4$ \\
DNCB $0.5 \mathrm{mmol} / \mathrm{L}$ & + & $30.1 \pm 10.4$ \\
DNCB $1 \mathrm{mmol} / \mathrm{L}$ & + to ++ & $39.3 \pm 17.6$ \\
DNCB $2 \mathrm{mmol} / \mathrm{L}$ & ++ & $61.2 \pm 20.4^{*}$ \\
SDS $1 \mathrm{mmol} / \mathrm{L}$ & + & $29.5 \pm 11.8$ \\
\hline
\end{tabular}

${ }^{\text {a }}$ Data are the means \pm S.D. of three or four values.

CD86 immunostaining : + , light brown ; + to ++ , brown ; ++ , dark brown.

IL-4 release measured after 24-h incubation.

Significantly different from the control group, ${ }^{*} p<0.05$.

Table-2 Effect of DNCB concentration on CD86

\begin{tabular}{cc}
\multicolumn{2}{c}{ expression of NHDC in collagen gel. } \\
\hline $\begin{array}{c}\text { DNCB concentration } \\
(\mathrm{mmol} / \mathrm{L})\end{array}$ & CD86 expression \\
\hline 0 & + \\
0.2 & + to ++ \\
1 & ++ \\
\hline
\end{tabular}

CD86 immunostaining : + , light brown $;+$ to + + , brown; ++ , dark brown.

CD86 expression measured after 24-h incubation.

expression in NHDC. Less DNCB induced CD86 expression in the dendritic cell monolayer or the dendritic cell in collagen gel on comparison with CD86 expression in KDF-Skin. These results suggested that because of the barriereffect of keratinocytes, a higher amount of DNCB induced CD86 expression in KDF-Skin than in a human skin model consisting of only dendritic cells, and that the skin model might overestimate the immunoreaction of real skin in comparison with KDF-Skin. In addition, our skin model has the advantages of

1) The application of water-insoluble samples (organic compounds and cosmetics, etc.).

2) A long life for culturing dendritic cells.

3) The ability to investigate the indirect effect of test chemicals on dendritic cells, like CD86 expression.

On the other hand, our skin model has the following disadvantages :

1) The horny layer of keratinocytes in this skin model is thinner than that of keratinocytes in real human skin.

2) Evaluation of CD86 expression in the dendritic cell is qualitative.

Further study should be done to solve these problems.

\section{References}

1) A. C. A. De Smedt, R. L. Van Den Heuven, N. Z. Berneman, G. E. R. Schoeters, Toxicol. in Vitro, 15, 319-325 (2001)

2) M. Furue, H. Uchi, T. Nakahara, Y. Moroi, J. Jpn. Cosmet. Sci. Soc., 28, 183-186 (2004)

3) Y. Yoshida, H. Sakaguchi, Y. Ito, M. Okuda, H. Suzuki, Toxicol. in Vitro, 17, 221-228 (2003)

4) E. Bell, N. Parenteau, R. Gay, C. Nolte, P. Kemp, P. Bilbo, B. Ekstein, E. Johnson, Toxicol. in Vitro, 5, 591-596 (1991)

5) A. L. Rheins, M. S. Edwards, O. Miyo, A. T. Donnelly, Toxicol. in Vitro, 8, 1007-1014 (1994) 
6) K. Morota, N. Morikawa, S. Morita, H. Kojima, H. Konishi, Tissue Culture Res. Com., 17, 87-93 (1998)

7) K. Morota, N. Morikawa, S. Morita, H. Kojima, H. Konishi, Alternative Test Experiment, 6, 41-51 (1999)

8) S. Aiba, H. Manome, Y. Yoshino, H. Tagami, Immunology, 101, 68-75 (2000)

9) M. J. Staquet, M. Sportouch, C. Jacqet, D. Schmitt, J. Guesnet, J. Peguet-Navarro, Toxicol. in Vitro, 18, 493-500 (2004)

10) A. Coquette, N. Berna, A. Vandenbosch, M. Rosdy, B. De Wever, Y. Poumay, Toxicol. in Vitro, 17, 311-321 (2003)

11) K. H. Ryu, S. J. Cho, Y. J. Jung, J. Y. Seoh, J. H. Kie, S. H. Koh, H. J. Kang, H. S. Ahn, H. Y. Shin, Int. J. Hematol., 80, 281-286 (2004)

12) T. Uchino, H. Tokunaga, M. Ando, in Proceedings of the 122 nd Annual Meeting of the Pharmaceutical Society of Japan, Vol. 3, 2002, p. 193

\title{
ケラチノサイト，樹状細胞，線維芽細胞を含む 3 次元培養ヒト皮膚モデルの 構築と皮膚感作性の動物実験代替法への応用*
}

\author{
内 野 正，五十嵐良明，徳 永 裕 司 \\ 国立医薬品食品衛生研究所 環境衛生化学部**
}

\begin{abstract}
皮膚感作性のインビトロ評価法を開発するために，わ坊れはケラチノサイト，樹状細胞，線維芽細 胞を含む 3 次元培養ヒト皮虐モデルの構築を試みた。皮虚モデル中の細胞の生死は HE 染色を行って観 察した。角層形成後の $11 \sim 14$ 日目のモデルを試験に用いた。細胞毒性を発現しない濃度の DNCB 添 加時において，ケラチノサイト，樹状細胞からの IL-4 放出および樹状細胞の CD 86 発現が誘導された。 一方，非感作性物質の SDS 添加時は IL-4 放出㧍よびCD86 発現の誘導は見られなかった。これらの結 果から，この皮膚モデルが皮膚感作性物質の動物実験代替法に適用できる可能性が示唆された。
\end{abstract}

